\title{
Calibration and validation of algorithms for the estimation of chlorophyll-a concentration and Secchi depth in inland waters with Sentinel-2
}

\author{
Marcela Pereira-Sandoval ${ }^{1, *}$, Esther Patricia Urrego ${ }^{1}$, Antonio Ruiz-Verdú ${ }^{1}$, Carolina Tenjo ${ }^{1}$, \\ Jesús Delegido $^{1}$, Xavier Soria-Perpinyà ${ }^{2}$, Eduardo Vicente ${ }^{2}$, Juan Soria ${ }^{2}$ and José Moreno ${ }^{1}$ \\ ${ }^{1}$ IPL - University of Valencia. Catedrático José Beltrán, 2. 46980 Paterna, Valencia (Spain). \\ 2 Institut Cavanilles de Biodiversitat i Biología Evolutiva (ICBiBE). Universitat de València. C/ Catedrático José \\ Beltrán, 2. 46980-Paterna, València, (Spain). \\ * Corresponding author: Marcela.Pereira@uv.es
}

Received: 09/03/18 Accepted: $12 / 09 / 18$

\begin{abstract}
Calibration and validation of algorithms for the estimation of chlorophyll-a concentration and Secchi depth in inland waters with Sentinel-2

Chlorophyll- $a$ concentration and Secchi disk depth are two of the most important biophysical parameters used to assess water quality and determine the ecological state of inland waters. The Ocean Color 2 and Dall'Olmo three-band algorithms were used to estimate chlorophyll- $a$ concentration and the calibration of the ratio 490/705 nm was used to produce an algorithm for estimating Secchi disk depth. These algorithms have been calibrated for the Sentinel 2-Multispectral Instrument (S2-MSI) and validated using in situ measurements of chlorophyll- $a$, Secchi disk depth and radiometry. This data was taken in the Valencia region reservoirs as part of the project Ecological Status of Aquatic Systems with Sentinel Satellites (ESAQS). The results show that for estimating chlorophyll- $a$ concentration, it is better to apply a prior classification based on their trophic status. For eutrophic and hypertrophic waters, the TBDO algorithm had an error of $23 \mathrm{mg} / \mathrm{m}^{3}$ over a chlorophyll- $a$ concentration range of between 10 to $169 \mathrm{mg} / \mathrm{m}^{3}$. For ultraoligotrophic to mesotrophic waters, the better algorithm was OC2 490, which resulted in an error equal to $0.9 \mathrm{mg} / \mathrm{m}^{3}$ over a chlorophyll- $a$ concentration range of between 0.54 to $5.8 \mathrm{mg} / \mathrm{m}^{3}$. For the estimation of water transparency by Secchi disk depth, we have obtained good results with the ratio $490 / 705 \mathrm{~nm}$, with an error equal to $0.88 \mathrm{~m}$ over a Secchi disk depth range of between 0.26 to $8.1 \mathrm{~m}$. These algorithms have been applied to S2-MSI images and satisfactory results have been obtained for different reservoirs in the Valencia region (Spain).
\end{abstract}

Key words: Ocean Color, Dall'Olmo three-band, chlorophyll- $a$, Secchi disk depth, Sentinel-2, HydroLight

\section{RESUMEN}

Calibración y validación de algoritmos para la estimación de la concentración de la clorofila-a y profundidad de Secchi en aguas continentales con Sentinel-2

La concentración de clorofila-a y la profundidad del disco de Secchi son dos de los parámetros biofisicos más importantes utilizados para evaluar la calidad del agua y determinar el estado ecológico en aguas continentales. Los algoritmos Ocean Color 2 y triple banda de Dall'Olmo fueron aplicados para la estimación de la concentración de la clorofila-a. El ratio 490/705 nm se usó para producir un algoritmo para la estimación de la profundidad del disco de Secchi. Esos algoritmos han sido calibrados para el Instrumento Multiespectral de Sentinel 2 (S2-MSI) y validados usando medidas in situ de la clorofila-a, profundidad del disco de Secchi y radiometría. Estos datos se tomaron en los embalses de la región de Valencia en el contexto del proyecto Estado Ecológico de los Sistemas Acuáticos con Satélites Sentinel (ESAQS). Los resultados muestran que para la estimación de la concentración de la clorofila-a es mejor aplicar previamente una clasificación basada en su estado trófico. Para aguas eutróficas e hipertróficas, el algoritmo triple banda de Dall'Olmo tuvo un error de $23 \mathrm{mg} / \mathrm{m}^{3}$ sobre un rango de concentración de clorofila-a entre 10 a $169 \mathrm{mg} / \mathrm{m}^{3}$. Para aguas ultraoligotróficas a mesotróficas el mejor algoritmo fue el 
OC2_490, con el cual se obtuvo un error de $0.9 \mathrm{mg} / \mathrm{m}^{3}$ sobre un rango de concentración de clorofila-a entre 0.54 a $5.8 \mathrm{mg} / \mathrm{m}^{3}$. Para la estimación de la transparencia del agua mediante la profundidad del disco de Secchi, hemos obtenido buenos resultados con el ratio 490/705 $\mathrm{nm}$, con un error igual a $0.88 \mathrm{~m}$ sobre un rango de profundidad de disco de Secchi entre 0.26 a $8.1 \mathrm{~m}$. Estos algoritmos han sido aplicados a imágenes S2-MSI obteniendo resultados satisfactorios en diferentes embalses en la región de Valencia (España).

Palabras clave: Ocean Color, triple banda de Dall'Olmo, clorofila-a, profundidad de disco de Secchi, Sentinel-2, HydroLight

\section{INTRODUCTION}

Chlorophyll- $a$ concentration $[\mathrm{Chl}-a]$ is a phytoplankton biomass estimator in water bodies. It is one of the fundamental parameters of water quality used to detect algal blooms and assess eutrophication levels. The anomalous productivity of phytoplankton biomass relative to a "normal situation" (or the ecological optimum, depending on the watershed characteristics and climate of a given water body) is an indicator of eutrophication (Zheng and DiGiacomo, 2017). The [Chl- $a$ ] derivation from satellite data relies mostly on the absorption signal of phytoplankton. The variability of the [Chl- $a]$ specific absorption coefficient is spectrally minimal around the red absorption peak $(670 \mathrm{~nm})$, where the influence of accessory pigments is minimal, and is higher around the blue absorption peak $(440 \mathrm{~nm})$, where the absorption of accessory pigments and dissolved organic matter is also high (Bricaud et al., 1995; Stramsky et al., 2001, Zheng \& DiGiacomo, 2017).

Secchi disk depth $\left(\mathrm{Z}_{\mathrm{SD}}\right)$ is a measurement of water transparency. The depth at which the disk disappears into the water is inversely proportional to the average amount of organic and inorganic materials along the path of sight in the water. The sense of sight is an integral part of the measurement procedure (Preisendorfer, 1986).

The European Water Framework Directive (WFD) establishes a framework for community-wide action for assessing the ecological status, management and conservation of the different water bodies in the member states. In this context, and in view of the need for comprehensive management of the aquatic systems of the Valencia region (south-eastern Spain), the Ecological Status of Aquatic Systems with Sentinel satellites (ESAQS) project was developed. The Regional Water Authority (Confederación Hidrográfica del
Júcar, CHJ) collaborates and helps this project. The main objective of ESAQS is to develop and validate algorithms for the estimation of ecological quality indicators of inland waters (i.e. chlorophyll- $a$ concentration, Secchi depth, colored dissolved organic matter and suspended solids) using the data provided by the Multispectral Instrument (MSI) sensor on-board the Sentinel-2 (S2-MSI) mission. The MSI scenes have a spatial resolution of $10 \mathrm{~m}$, a high temporal resolution of 5 days and an adequate spectral resolution. Table 1 summarizes the principal features of S2-MSI. These characteristics make this sensor an exceptional instrument for the retrieval of biophysical parameters in inland waters, as compared to other satellite missions designed either for ocean color applications (e.g. the Ocean and Land Colour Imager, OLCI, on Sentinel-3 or the Moderate-Resolution Imaging Spectroradiometer, MODIS-Aqua), or the land-oriented Operational Land Imager (OLI) Landsat-8, which have a lower spatial resolution $(300,1000$ and $30 \mathrm{~m}$, respectively). S2-MSI data is suitable for the study of small irregularly-shaped water masses like most reservoirs in the region (Fig. 1) and small area as 80 ha (Regajo reservoir). Remote sensing data adds an extra value to limnological data collected from traditional in situ measurements (Giardino et al., 2001), thanks to the synoptic view and frequency of the satellite passes. Remotely-sensed optical imagery over water bodies has been used as a cost-effective way for monitoring water quality.

The aim of this paper is to present the results of the calibration of water quality algorithms for the estimation of [Chl- $a$ ] and $\mathrm{Z}_{\mathrm{SD}}$ from S2-MSI spectral bands and the validation with in situ [Chl- $a$ ] and $\mathrm{Z}_{\mathrm{SD}}$ measurements. These algorithms cover a wide range of trophic states, from hypertrophic to ultraoligotrophic, in line with the characteristics 
Table 1. Main characteristics of S2-MSI spectral bands. Principales características de las bandas espectrales de S2-MSI.

\begin{tabular}{cccc}
\hline Band number & $\begin{array}{c}\text { Central } \\
\text { wavelength } \\
(\mathbf{n m})\end{array}$ & $\begin{array}{c}\text { Bandwidth } \\
(\mathbf{n m})\end{array}$ & $\begin{array}{c}\text { Spatial } \\
\text { resolution }(\mathbf{m})\end{array}$ \\
\hline 1 & 443 & 20 & 60 \\
2 & 490 & 65 & 10 \\
3 & 560 & 35 & 10 \\
4 & 665 & 30 & 10 \\
5 & 705 & 15 & 20 \\
6 & 740 & 15 & 20 \\
7 & 783 & 20 & 20 \\
8 & 842 & 115 & 10 \\
$8 \mathrm{a}$ & 865 & 20 & 20 \\
9 & 945 & 20 & 60 \\
10 & 1380 & 30 & 60 \\
11 & 1610 & 90 & 20 \\
12 & 2190 & 180 & 20 \\
\hline
\end{tabular}
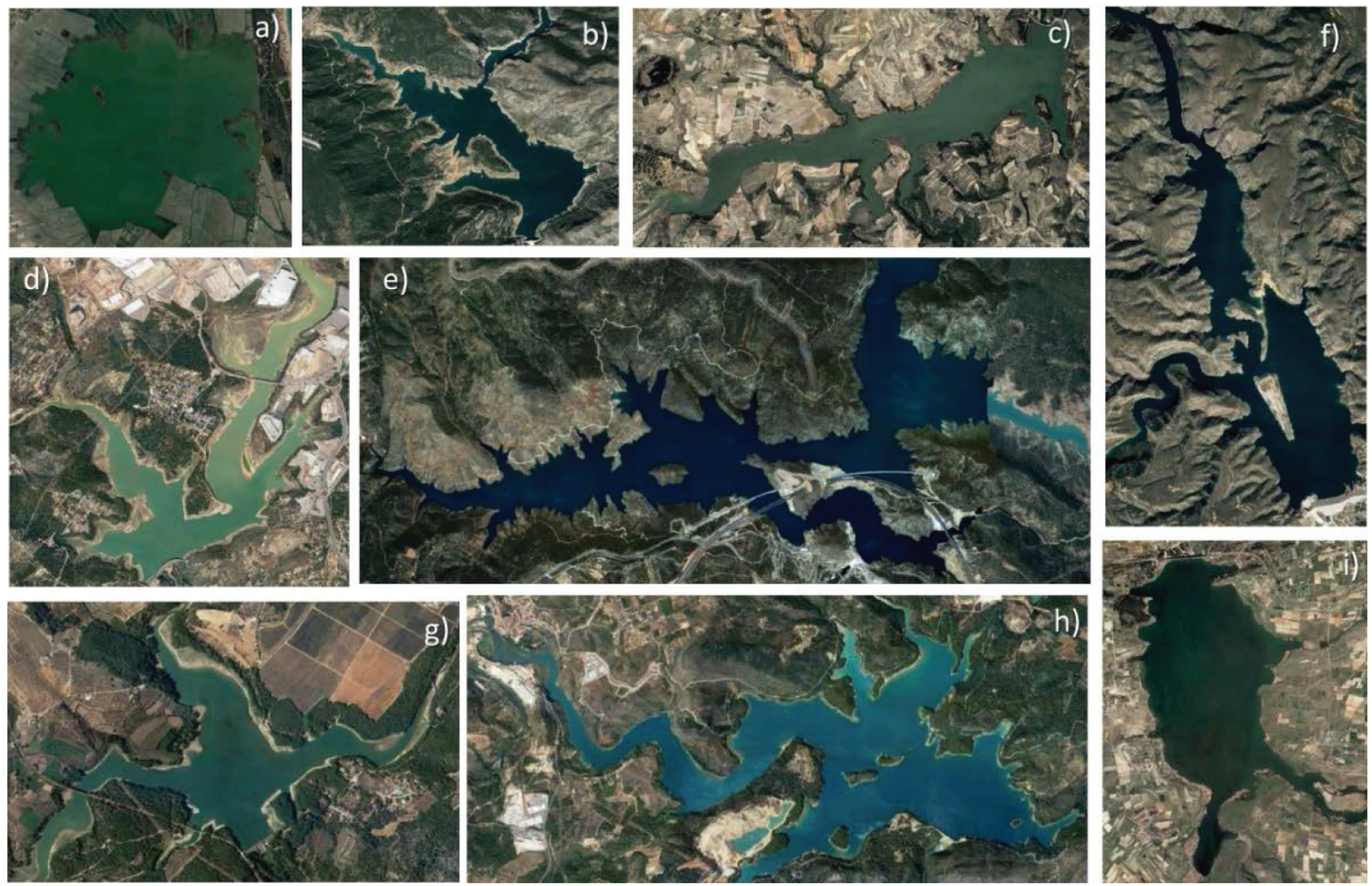

Figure 1. Reservoirs in study area. a) Albufera of Valencia, b) Benagéber, c) Beniarrés, d) María Cristina, e) Contreras, f) Tous, g) Regajo, h) Sitjar and i) Bellús. Embalses en el área de estudio. a) Albufera de Valencia, b) Benagéber, c) Beniarrés, d) María Cristina, e) Contreras, f) Tous, g) Regajo, h) Sitjar y i) Bellús. 
of reservoirs measured in our study region. This objective fits into the main ESAQS goal of formulating new algorithms for inland water ecological state monitoring from remote sensing.

\section{DATA AND METHODS}

\section{Study area}

Since 2017, the first year of the ESAQS project, a large number of field campaigns have been carried out in the Valencia region. The study area includes the reservoirs of Benagéber, Bellús, Beniarrés, Contreras, María Cristina, Regajo, Sitjar, Tous and the Albufera of Valencia (Fig. 2), covering a wide gradient of trophic states. For each reservoir, between 1 and 4 in situ measuring points were taken at a suitable distance from shoreline to avoid mixed pixels (land-water mixed reflectance). The field campaigns were planned on cloud-free days on which the S2 satellites acquired images over the reservoir region.

\section{In situ data: $[\mathrm{Chl}-a]$ and $\mathrm{Z}_{\mathrm{SD}}$}

[Chl- $a$ ] and $\mathrm{Z}_{\mathrm{SD}}$ were measured by the Limnology Research Team of the University of Valencia. [Chl- $a]$ data were obtained from the water samples by the spectrophotometric method. Samples were filtered through $0.4-0.6 \mu \mathrm{m} \mathrm{GF} / \mathrm{F}$ glass

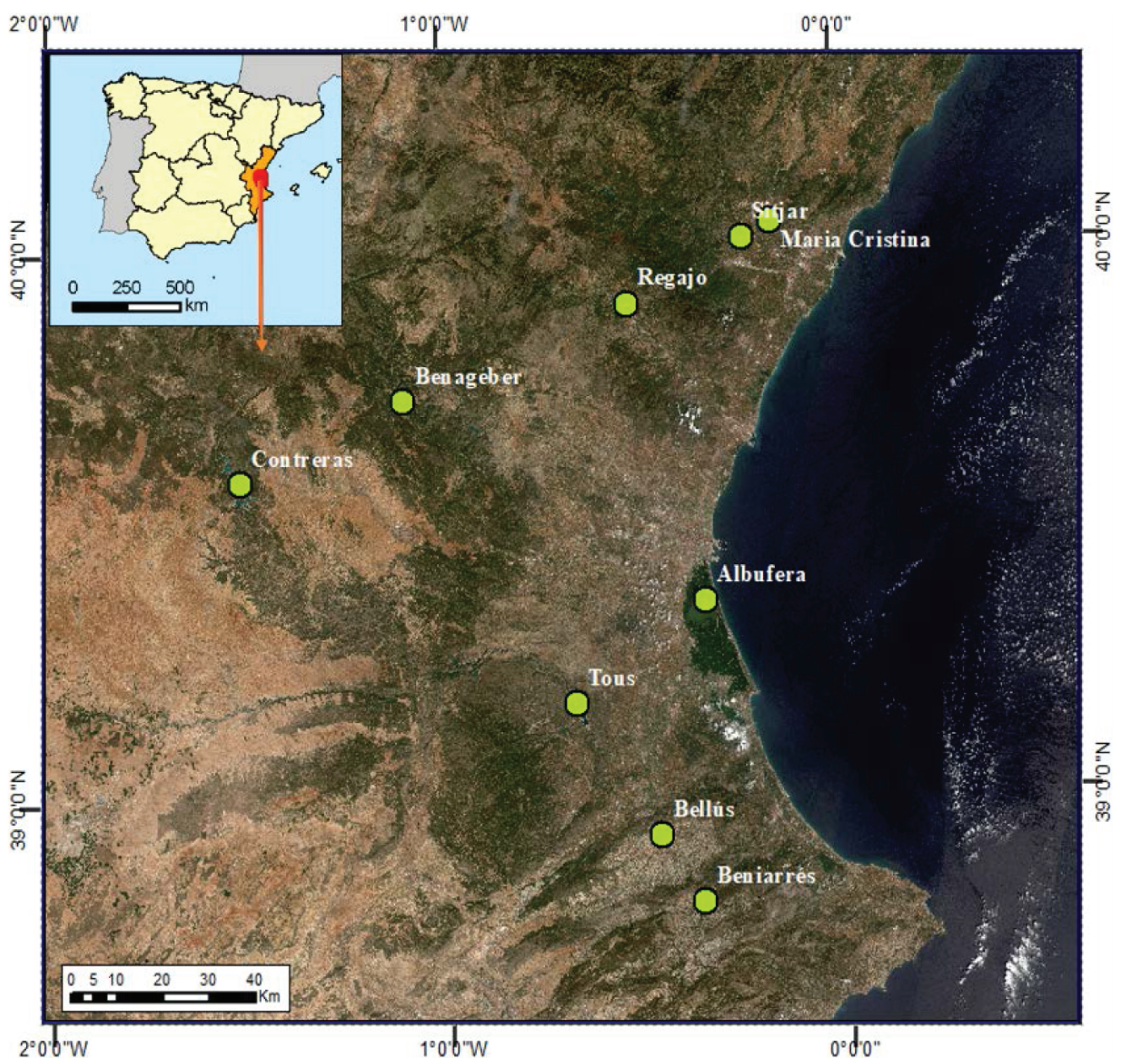

Figure 2. Location map of reservoirs and lakes in study in Valencia region. Mapa de localización de los embalses y lagos en estudio en la región de Valencia. 
fiber filters, extracted according to standard methods (Shoaf \& Lium, 1976) and the calculation methods by Jeffrey \& Humphrey (1975) (Soria et al., 2019). The range of in situ [Chl-a] measurements in the study area reservoirs was between 0.54 to $169 \mathrm{mg} / \mathrm{m}^{3}$.

$\mathrm{Z}_{\mathrm{SD}}$ data was measured with a metal disk called a Secchi disk. It is divided into four quarters, each one painted black and white. The measurement procedure for obtaining the $\mathrm{Z}_{\mathrm{SD}}$ is to slowly lower it into the water until it disappears from sight. When that happens, it is possible to obtain the $\mathrm{Z}_{\mathrm{SD}}$. The in situ $\mathrm{Z}_{\mathrm{SD}}$ measurement range in the reservoirs under study was between 0.25 to $10.5 \mathrm{~m}$.

\section{In situ reflectances}

The in situ reflectances were calculated from above-water in situ measurements of: 1) The water-leaving radiance $\left.\left(\mathrm{L}_{\mathrm{W}}\right), 2\right)$ the sky radiance $\left(\mathrm{L}_{\text {sky }}\right)$ and 3$)$ the downwelling solar irradiance $\left(E_{S}\right)$. These were measured using a HandHeld2 radiometer, which has a wavelength range of 325 to $1075 \mathrm{~nm}$ and a spectral resolution of $1 \mathrm{~nm}$; and an Ocean Optics (HR 4000) radiometer ranging from 200 to $1100 \mathrm{~nm}$ at a spectral resolution of $\sim 0.2 \mathrm{~nm}$. According to previous studies (Mobley, 1999) and recommendations done by international remote sensing ocean groups (Fargion \& Mueller, 2000), the measurements have been taken with a view zenith angle of $\sim 45^{\circ}$ and an azimuthal angle of $\sim 135^{\circ}$, with respect to the sun, to minimize the direct and diffuse sunlight reflected by the water surface (Mobley, 1999). Once the measurements were obtained, the in situ reflectance spectrum was convolved to the S2-MSI spectral bands (Table 1). This procedure was done to fit the in situ reflectance spectral resolution $(\sim 0.2 \mathrm{~nm}$ or $1 \mathrm{~nm})$ to $\mathrm{S} 2-\mathrm{MSI}$ bandwidth using the Spectral Response Functions database (SRF v2.0) (ESA, 2018a). The SRF determine the position and width of each S2-MSI spectral band (D'Odorico et al., 2013).

\section{S2-MSI imagery}

The Cloudless Level 1C S2-MSI images were downloaded from the Copernicus Open Access
Hub of the European Spatial Agency (ESA, 2018 b) to be concurrent with the in situ measurements. SNAP software v.5.0 (ESA, 2018c) was used for the image processing. For the specific case of the Albufera of Valencia, images were atmospherically corrected to Bottom of Atmosphere (BOA) reflectances using the Sen2Cor processor (ESA, 2018d). While this atmospheric correction method was designed for land products, it gives back optimum results in eutrophic waters like the Albufera of Valencia according to Ruescas et al. (2016) and Soria et al. (2017a). In this respect, we would highlight the importance of atmospheric correction over inland waters. In the ESAQS project, we are evaluating different atmospheric correction methods to obtain an optimum retrieval of the algorithms calibrated and validated to actual S2-MSI images for routine monitoring purposes.

\section{Calibration and validation of established [Chl-a] algorithms}

To calibrate the [Chl- $a$ ] algorithms and encompass the variability of the optically active components present in inland waters, we generated a calibration database of simulated data $(\mathrm{N}=392)$ by using the radiative transfer model HydroLight (Mobley, 1994). We carried out simulations with a three-component Case-2 model with ranges of variables characteristics for oligotrophic to eutrophic waters: [Chl- $a$ ] $\left(1-500 \mathrm{mg} / \mathrm{m}^{3}\right)$, Colored Dissolved Organic Matter (CDOM) (0.01-4 $\mathrm{m}^{-1}$ ) and Non-Algal Particles (NAP) (0.1-100 $\left.\mathrm{g} / \mathrm{m}^{3}\right)$. To estimate [Chl- $a$ ] with S2-MSI spectral bands, we tested the Ocean Color 2_443 nm (OC2_443) and Ocean Color 2 $490 \mathrm{~nm}$ (OC2 490 ) (replacing the original 483 band with the $4 \overline{9} 0$ band in S2-MSI), the Ocean Color 3 (OC3) (O'Reilly et al., 2000) and the Dall'Olmo three-band algorithm (Dall'Olmo et al., 2003), hereafter called the TBDO algorithm. Following the methodology of Ruiz-Verdú et al. (2016), the OC2 and OC3 algorithms, based on the ratio of green and blue bands, have been recalibrated for the S2-MSI spectral bands. The TBDO algorithm, which is based on the evaluation of the reflectance at red and near infrared bands $(665,705$ and $740 \mathrm{~nm}$ ), is used for the estimation of [Chl- $a$ ] in 
inland and coastal water (Gilerson et al., 2010). This algorithm has also been calibrated for the S2-MSI spectral bands and validated in a previous work in a hypertrophic coastal lagoon: the Albufera of Valencia (Guibaja et al., 2016).

The $[$ Chl- $a]$ algorithms used in this work are described below. The general equation for the $\mathrm{OC} 2$ and $\mathrm{OC} 3$ models are:

$$
\log _{10}[\mathrm{Chl}-a]=\mathrm{a}+\mathrm{bX}+\mathrm{cX}^{2}+\mathrm{dX}^{3}
$$

where $\mathrm{X}$ is calculated according to:

$$
\begin{aligned}
& \text { OC2_443 model } \\
& \text { X }=\log _{10}[\text { Rrs_443/Rrs_560] }
\end{aligned}
$$

OC2 490 model

$$
\mathrm{X}=\log _{10} \text { [Rrs_490/Rrs_560] }
$$

OC3 model

$$
X=\log _{10} \text { [max (Rrs_443; Rrs_490)/Rrs_560] }
$$

The Rrs_443, Rrs_490 and Rrs_560 are reflectances of S2-MSI spectral bands.

The algorithm called OC2 490, fit to the S2-MSI bands, is set to the spectral band 490.

The three-band model of Dall'Olmo et al. (2003) (TBDO), takes the form:

$$
[\mathrm{Chl}-a]=\mathrm{aX}+\mathrm{bX}+\mathrm{c}
$$

where

$$
\mathrm{X}=\left[\operatorname{Rrs} \_740 *\left(\left(\operatorname{Rrs} \_665\right)^{-1}-\left(\operatorname{Rrs} \_705\right)^{-1}\right)\right]
$$

The Rrs_665, Rrs_705 and Rrs_740 are reflectances of S2-MSI spectral bands.

Once the different algorithms were calibrated from the HydroLight database, we validated it with the [Chl- $a$ ] field data, selecting the best method according to different statistical parameters. If a linear trend is maintained, but away from the 1:1 line, the algorithms were recalibrated.

\section{Calibration and validation of $\mathrm{Z}_{\mathrm{SD}}$ algorithms}

The attenuation of light into water bodies and the vertical visibility (water transparency) is described by the Secchi disk depth $\left(Z_{S D}\right)$. It is linked to two optical parameters: the vertical diffuse attenuation coefficient $\mathrm{K}_{\mathrm{d}}\left(\mathrm{m}^{-1}\right)$ and the attenuation coefficient $\mathrm{c}\left(\mathrm{m}^{-1}\right)$ (Antoine, 2010). The vertical visibility is analogous to $\mathrm{Z}_{\mathrm{SD}}$ and it is the inverse of the sum $\mathrm{K}_{\mathrm{d}}+\mathrm{c}$ (Doron et al., 2007). Austin and Petzold, (1981) estimated $K_{d}$ $(490 \mathrm{~nm})$ from blue-green water leaving radiances. This algorithm was modified by Kratzer et al., (2008) to estimate $Z_{\text {SD }}$ for remote sensing applications (Alikas \& Kratzer, 2017). The ratio $490 / 560$ is used to map transparency over clear waters, typically in open ocean waters (Mueller, 2000; Giardino et al., 2001; Antoine, 2010; Soria et al., 2017b). This ratio is a good estimator of $\mathrm{Z}_{\mathrm{SD}}$ in clear waters in which the phytoplankton is the main contributor to the light attenuation in the water column.

To estimate the transparency of the water in this work, we have performed a process of re-calibration of the 490/560, and 490/705 ratios, plus the hereafter called "Koponen" method (Koponen et al., 2001) after testing different algorithms. We have modified the original Alikas \& Kratzer (2017) algorithm. In this paper, the band ratio are not raised to the exponent $b$. Instead, the b coefficient is added or subtracted depending on the direction of the slope, obtained in the relation between in situ Secchi disk depth $\left(\mathrm{Z}_{\mathrm{SD}}\right)$ measurements and band ratio. The algorithm is detailed in equation 7 :

$$
\mathrm{Z}_{\mathrm{SD}}=\mathrm{e}^{\wedge}\left(\mathrm{a} * \ln \left[\operatorname{Rrs} \_490 / \operatorname{Rrs} \_560\right]+\mathrm{b}\right)
$$

where

Rrs 490 and Rrs 560 are reflectances of S2-MSI spectral bands at 490 and $560 \mathrm{~nm}$.

$\mathrm{a}$ and $\mathrm{b}$ are the coefficients derived by linear regression between the Napierian logarithm of in situ $\mathrm{Z}_{\mathrm{SD}}$ and the Napierian logarithm of $490 / 560$ ratio.

Alikas \& Kratzer (2017) applied another model based on ratio 490/705. This model had a better result $\left(\mathrm{R}^{2}=0.73\right)$ in the Himmerfjärden lake with a 1.9 to $7.5 \mathrm{~m} \mathrm{Z}_{\mathrm{SD}}$ and a 1.2 to 11.6 $\mathrm{mg} / \mathrm{m}^{3}[$ Chl- $a$ ] range (Baltic Sea). The algorithm is detailed in equation 8 : 


$$
\mathrm{Z}_{\mathrm{SD}}=\mathrm{e}^{\wedge}\left(\mathrm{a} * \ln \left[\mathrm{Rrs} \_490 / \mathrm{Rrs} \_705\right]+\mathrm{b}\right)
$$

where

Rrs_490 and Rrs_705 are reflectances of S2-MSI spectral bands at 490 and $705 \mathrm{~nm}$.

$a$ and $b$ are the coefficients derived by linear regression between Napierian logarithm of in situ $\mathrm{Z}_{\mathrm{SD}}$ and the Napierian logarithm of 490/705.

In more turbid waters, where other optically active constituents such as NAP and CDOM are also present in significant concentrations, other spectral regions are more sensitive for estimating the $Z_{\mathrm{SD}}$ (Doron et al., 2007). Since this was the present situation in some reservoirs studied in ESAQS, other algorithms were also tested, such as the Koponen et al., (2001) algorithm. This algorithm was validated in Finnish Lakes where the water bodies generally present $\mathrm{Z}_{\mathrm{SD}}$ values of less than $3 \mathrm{~m}$. We have modified the original algorithm since we have not applied the 783 band. The modified Koponen algorithm is detailed in equation 9:

$$
\mathrm{Z}_{\mathrm{SD}}=\mathrm{e}^{\wedge}\left(\mathrm{a}^{*} \ln \left[\mathrm{Rrs} \_560 / \operatorname{Rrs} \_705\right]+\mathrm{b}\right)
$$

where

$\mathrm{a}$ and $\mathrm{b}$ are the coefficients derived by linear regression between Napierian logarithm of in situ $\mathrm{Z}_{\mathrm{SD}}$ and the Napierian logarithm of 560/705.

The Rrs_560 and Rrs_705 are reflectances of S2-MSI spectral bands.

\section{RESULTS}

The $C \mathrm{Z}_{\mathrm{SD}}$ measurement range in the water bodies under study was between 0.25 to $10.5 \mathrm{~m}$. The range of Limnetica, 38(1): 467-479 (2019). DOI: $10.23818 /$ limn.38.26 [Chl- $a$ ] measurements in the study area water bodies was between 0.54 to $169 \mathrm{mg} / \mathrm{m}^{3}$.

\section{Calibration and validation of $[\mathrm{Chl}-a]$ algo- rithms}

In the set of simulated data used for calibration, the input $[\mathrm{Chl}-a]$ presented a very high correlation, according the coefficient of determination $\left(\mathrm{R}^{2}\right)$, with the retrieved [Chl- $a$ ] in all algorithms: OC2_443 with a R2 $=0.98$ (Fig. 3a); OC2_490 with $\overline{\mathrm{R}}^{2}=0.97$; (Fig. 3b); OC 3 with $\mathrm{R}^{2}=0.97$ (Fig. 3c); and TBDO with $\mathrm{R}^{2}=0.99$ (Fig. 3d). The specific calibration coefficients of each algorithm were obtained by a polynomial fit between the simulated [Chl- $a$ ] database and reflectance band ratios. Table 2 summarizes the coefficients of each polynomial fit.

To validate these algorithms, the data measured in the field was used. Table 3 shown this dataset. According to Guibaja et al. (2015), the TBDO algorithm had an optimum performance on eutrophic and hypertrophic waters. In our study area, this type of water corresponds to reservoirs with $[$ Chl- $a]>10 \mathrm{mg} / \mathrm{m}^{3}$ like the Albufera of Valencia, and the Bellús and Beniarrés reservoirs (Table 3). For [Chl-a] $<10 \mathrm{mg} / \mathrm{m}^{3}$, we have applied the OC2_443, OC2_490 and OC3 algorithm on ultraoligotrophic, oligotrophic and mesotrophic waters. These water types correspond to the Benageber, Tous, María Cristina, Contreras, Sitjar and Regajo reservoirs (Table 3). The error analysis was performed between the calibrated algorithms and in situ [Chl-a] measurements. For this analysis, we have applied the mean absolute error (MAE) and a systematic direction of the error (bias). Figure 4 shows the [Chl- $a$ ] measured in situ versus the calculated with the 4 algorithms. In the OC2_443, OC2_490 and OC3 algorithms, it can be seen that the slope presented values very far from line $1: 1(0.25$ and 0.30$)$ (Fig. $4 \mathrm{a}, \mathrm{b}$ and c) with a very high bias. This means that in these cases, ocean color models are overestimating the actual chlorophyll concentration, with high error values. For this reason, it was necessary to perform a recalibration process to readjust each of the models. Table 4 shows the final equation, which was obtained from the recalibration process for the [Chl- $a$ ] estimation, replacing the $\mathrm{x}$ of each adjustment (Fig. 4 a, b and c) the formulas obtained in the calibration process. For this, the value of the line slope (coefficient a) was integrated logarithmically in equation 1 .

According to Table 4 data, all three algorithms provide similar statistics, but the OC3 was the algorithm which gave back the lowest error equal 

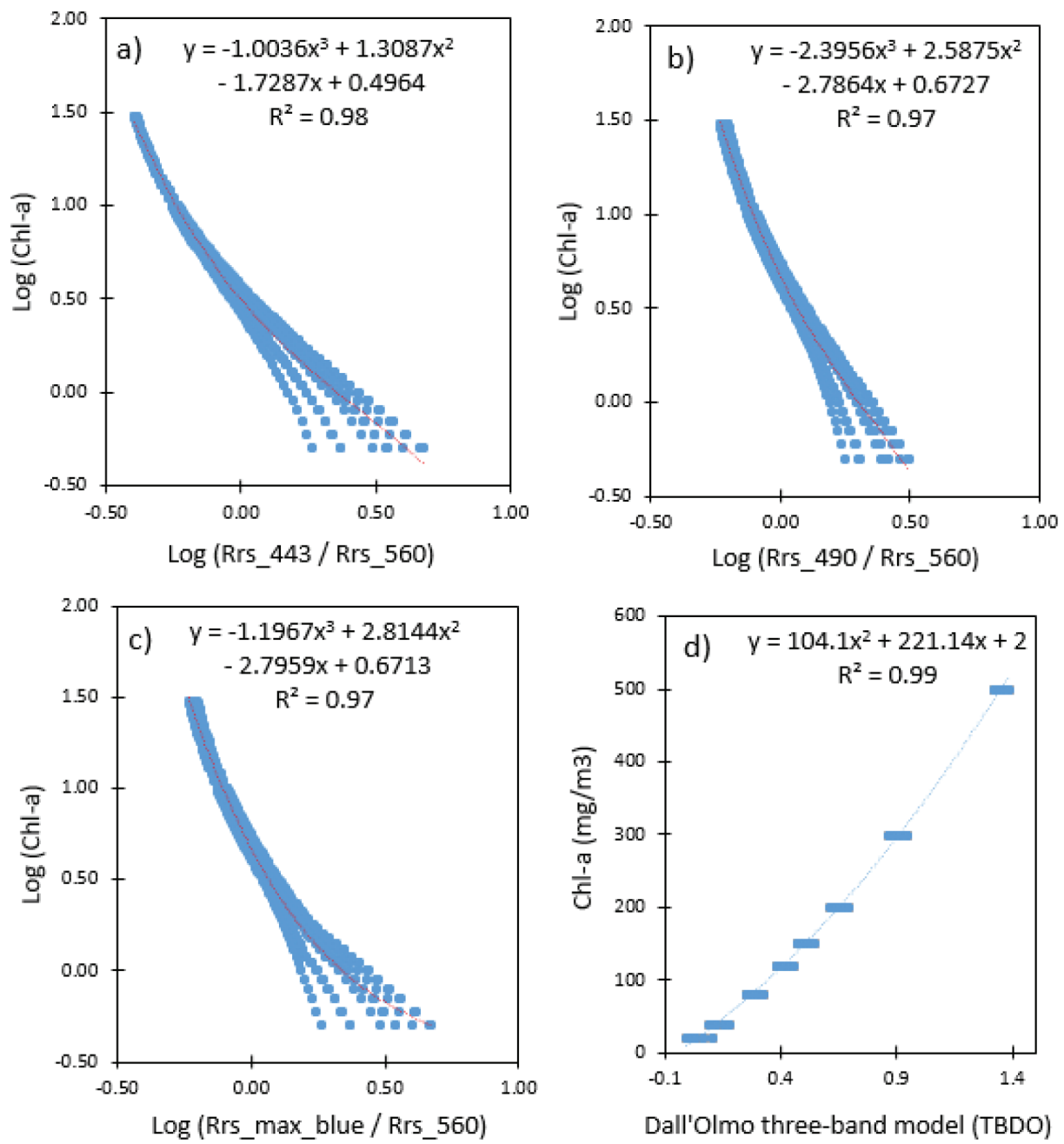

Figure 3. a) OC2_443 algorithm and simulated [Chl- $a$ ] polynomial fit. b) OC2_490 algorithm and simulated [Chl- $a$ ] polynomial fit. c) OC3 algorithm and simulated [Chl- $a$ ] polynomial fit, and d) TBDO algorithm and simulated [Chl-a] polynomial fit. a) Ajuste polinómico entre el algoritmo OC2_443 y la [Chl-a] simulada. b) Ajuste polinómico entre el algoritmo OC2_490 y la [Chl-a] simulada. c) Ajuste polinómico entre el algoritmo OC3 y la [Chl-a] simulada, y d) Ajuste polinómico entre el algoritmo TBDO y la [Chl-a] simulada.

Table 2. Coefficients obtained by polynomial fit for OC2 443, OC2 490, OC3 and TBDO algorithms for [Chl- $a$ ] estimation (in $\mathrm{mg} / \mathrm{m}^{3}$ ) from simulated HydroLight dataset. Coeficientes obtenidos por ajuste polinomial para los algoritmos OC2_443, OC2_490, OC3 y TBDO para la estimacion de la [Chl-a] (en $\mathrm{mg} / \mathrm{m}^{3}$ ) a partir de una base de datos simulada con HydroLight.

\begin{tabular}{clccc}
\hline Algorithm & a & b & c & d \\
\hline OC2_443 & 0.4964 & -1.7287 & 1.3087 & -1.0036 \\
OC2_490 & 0.6727 & -2.7864 & 2.5875 & -2.3956 \\
OC3 & 0.6713 & -2.7959 & 2.8144 & -1.1967 \\
TBDO & 104.1 & 221.1 & 2.0 & \\
\hline
\end{tabular}


Table 3. Database of in situ [Chl- $a$ ] and Secchi depth disk measurements in Valencia region reservoirs and lakes according by field campaign date. Base de datos de medidas in situ de [Chl-a] y profundidad del disco de Secchi en los embalses y lagos de la región de Valencia según fecha de campaña de campo.

\begin{tabular}{|c|c|c|c|}
\hline Reservoir & {$[\mathrm{Chl}-a]\left(\mathrm{mg} / \mathrm{m}^{3}\right)$} & $\mathrm{Z}_{\mathrm{SD}}(\mathrm{m})$ & Date \\
\hline Albufera & $51.3,53,54.2,31.8,39.1,43.1$ & & $05 / 08 / 2015$ \\
\hline Albufera & $54.8,56.3,56.1,52.9,55.2,58.3$ & & $27 / 08 / 2015$ \\
\hline Albufera & $148.9,157.9,156,169.1,159.4,154,93.3$ & & $30 / 11 / 2015$ \\
\hline Albufera & $135.6,138.2,121.5,25,128.7$ & $0.31,0.31,0.33,0.43,0.32$ & $12 / 03 / 2016$ \\
\hline Albufera & $141.8,130.4,140.1,114.6,78.1,84.4,83.2$ & $0.25,0.26,0.3,0.35,0.26,0.33$ & $21 / 04 / 2016$ \\
\hline Albufera & $70.4,68,22.4,10.7,36.4,43.5$ & $0.3,0.32,0.33,0.34,0.34,0.37,0.5$ & $02 / 05 / 2016$ \\
\hline Tous & $1.27,1.78,3.1$ & $5.9,6,5.8$ & $27 / 12 / 2016$ \\
\hline Bellús & 31.8 & 1 & $16 / 01 / 2017$ \\
\hline Contreras & $2,1,0.79,0.83$ & $1,1.3,1.07$ & $08 / 02 / 2017$ \\
\hline Albufera & $39.7,64.5,45.1,47.3$ & $0.27,0.32,0.34,0.36$ & $07 / 03 / 2017$ \\
\hline Beniarrés & 45.45 & 0.95 & $27 / 03 / 2017$ \\
\hline Benagéber & $2.48,2.74$ & $4,5.2,7.4$ & $30 / 03 / 2017$ \\
\hline Ma. Cristina & $1.4,1.33$ & $5.2,5.6$ & $06 / 04 / 2017$ \\
\hline Sitjar & $0.54,0.65$ & $9.4,10.5$ & $06 / 04 / 2017$ \\
\hline Bellús & $61.39,66.76,68.01$ & 0.55 & $15 / 06 / 2017$ \\
\hline Regajo & $8.6,8.9,10.2$ & $2,1.7$ & $05 / 07 / 2017$ \\
\hline Sitjar & $0.68,0.61$ & $2.7,3.15$ & $23 / 10 / 2017$ \\
\hline Benageber & $5.4,5.76,4.57$ & $3.4,3.6,4.1$ & $26 / 10 / 2017$ \\
\hline Beniarrés & $11.13,17.17$ & $1.15,1.4$ & $07 / 11 / 2017$ \\
\hline Tous & $0.64,0.72,0.69$ & $7.1,8,9.1$ & $17 / 11 / 2017$ \\
\hline Contreras & $2.08,2.42,2.02,0.86,0.98$ & $4.1,5$ & $30 / 11 / 2017$ \\
\hline Tous & $0.63,0.58,0.69$ & $7,7.75,8.1$ & $16 / 01 / 2018$ \\
\hline Ma. Cristina & $2.92,2.72$ & $0.75,0.75$ & $31 / 01 / 2018$ \\
\hline Sitjar & $0.59,0.63$ & $2.4,2.2$ & $31 / 01 / 2018$ \\
\hline Benageber & & $4.3,4.85,5.5$ & $23 / 02 / 2018$ \\
\hline Albufera & $84.5,82.1,81.6$ & $0.31,0.33,0.30$ & $07 / 03 / 2018$ \\
\hline Bellús & $41.54,51.59,49.09$ & $0.45,0.45,0.5$ & $22 / 03 / 2018$ \\
\hline Regajo & $5.57,4.58,4.63,5.12$ & $3,3.75,4,4.25$ & $11 / 05 / 2018$ \\
\hline Benageber & $4.91,4.91,4.85,4.53$ & $3.35,3.35,3.7,3.75$ & $16 / 05 / 2018$ \\
\hline
\end{tabular}



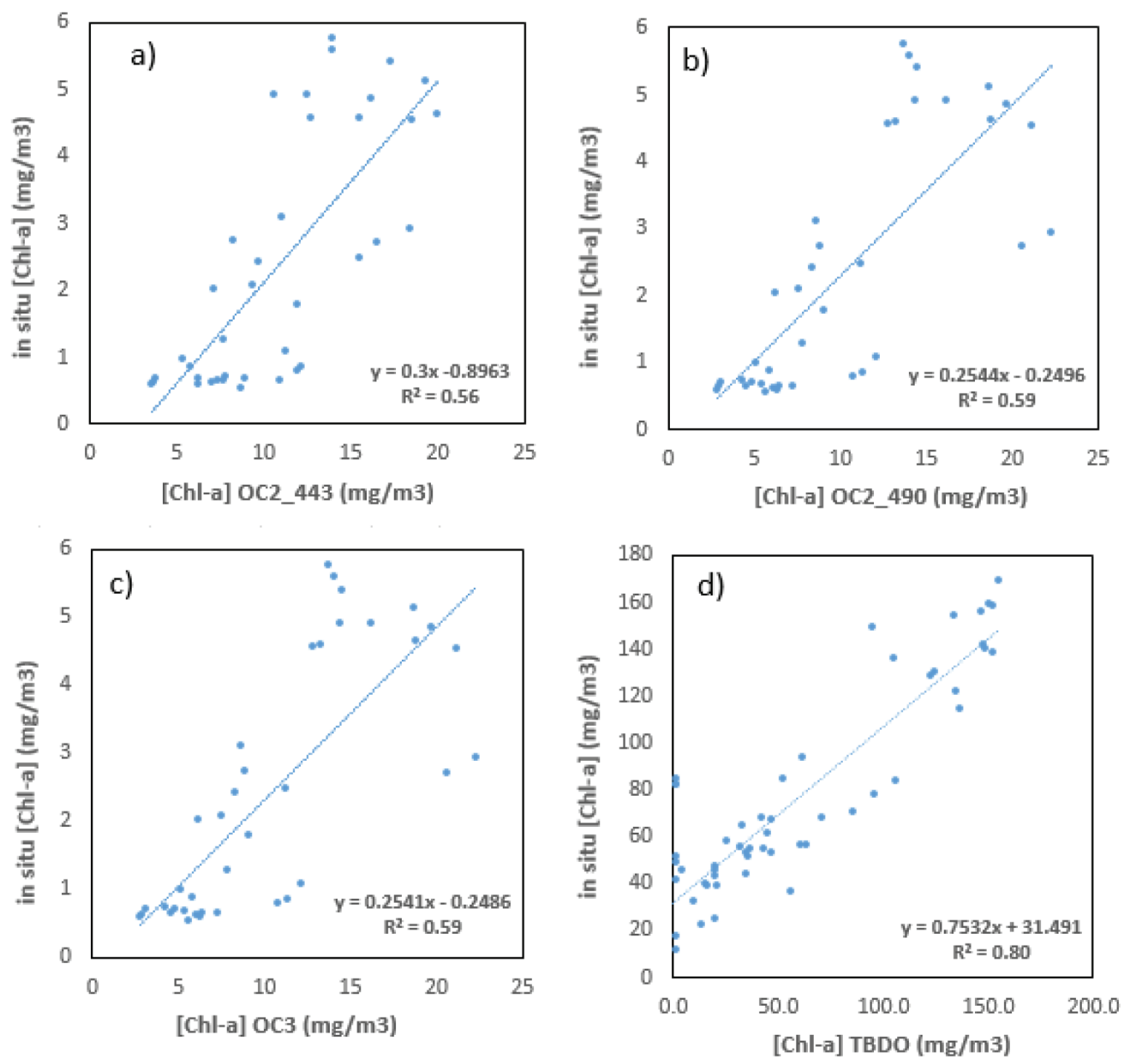

Figure 4. a) OC2_443 algorithm and in situ [Chl-a] validation. b) OC2_490 algorithm and in situ [Chl-a] validation. c) OC3 algorithm and in situ [Chl-a] validation, and d) TBDO algorithm and in situ [Chl-a] validation. a) Validación del algoritmo OC2_443 en relación a la [Chl-a] in situ. b) Validación del algoritmo OC2_490 en relación a la [Chl-a] in situ. c) Validación del algoritmo OC3 en relación a la [Chl-a] in situ, and d) Validación del algoritmo TBDO en relación a la [Chl-a] in situ.

to $0.89 \mathrm{mg} / \mathrm{m}^{3}$. However, the OC2_490 model also has very good results, with the same correlation as OC3 and the advantage that it is easier to calculate, saving processing time and using only one blue band, versus OC3 that he need to use both.

For eutrophic waters with [Chl- $a]>10 \mathrm{mg} / \mathrm{m}^{3}$, the TBDO algorithm (Fig. 4d) gave an $\mathrm{R}^{2}=0.80$, a bias $=17.49$ and an $\mathrm{MAE}=23 \mathrm{mg} / \mathrm{m}^{3}$, which is a relative low error for high [Chl- $a$ ] waters, taking into consideration the range of values for this group (10 to $169 \mathrm{mg} / \mathrm{m}^{3}$ ). We consider it acceptable for the evaluation of the ecological status in these eutrophic or hypertrophic reservoirs (Guibaja et al., 2016). The validated TBDO algorithm was applied to an S2-MSI image from the Albufera of Valencia acquired on 07/03/2018. This S2-MSI image was atmospherically corrected with Sen2Cor. Fig. 5 shows the patterns of [Chl- $a$ ] concentration with medium to high values in nearly the entire lake with a [Chl- $a$ ] TBDO, between 75 and $90 \mathrm{mg} / \mathrm{m}^{3}$. The same day, the in situ [Chl- $a$ ] measurements recorded in the Albufera of Valencia were between 81.6 to $84.5 \mathrm{mg} / \mathrm{m}^{3}$ (Table 3 ). The green areas correspond to the water contributions with less chlorophyll- $a$ coming from the irrigation channels renovating the water, while the central area corresponds to stagnant water, which leads to higher values of [Chl- $a]$. 
Table 4. Equations for the [Chl-a] estimation (in $\mathrm{mg} / \mathrm{m}^{3}$ ) in the calibration process. Ecuaciones para la estimación de la [Chl-a] (en $\mathrm{mg} / \mathrm{m}^{3}$ ) en el proceso de calibración.

\begin{tabular}{ccccc}
\hline Algorithm & Equation $\left([\mathrm{Chl}-a]\right.$ in $\left.\mathrm{mg} / \mathrm{m}^{3}\right)$ & MAE & $\mathbf{R}^{\mathbf{2}}$ \\
\hline OC2_443 & {$[\mathrm{Chl}-a]=10^{\wedge}\left(-0.02648-1.7287 * \mathrm{X}+1.3087^{*} \mathrm{X}^{\wedge} 2-1.0036^{*} \mathrm{X}^{\wedge} 3\right)-0.8963$} & 0.93 & 0.56 \\
OC2_490 & {$[\mathrm{Chl}-a]=10^{\wedge}\left(0.078217-2.7864 * \mathrm{X}+2.5875^{*} \mathrm{X}^{\wedge} 2-2.3956^{*} \mathrm{X}^{\wedge} 3\right)-0.2496$} & 0.90 & 0.59 \\
OC3 & {$[\mathrm{Chl}-a]=10^{\wedge}\left(0.076305-2.7959^{*} \mathrm{X}+2.8144^{*} \mathrm{X}^{\wedge} 2-1.1967 \mathrm{X}^{\wedge} 3\right)-0.2486$} & 0.89 & 0.59 \\
\hline
\end{tabular}

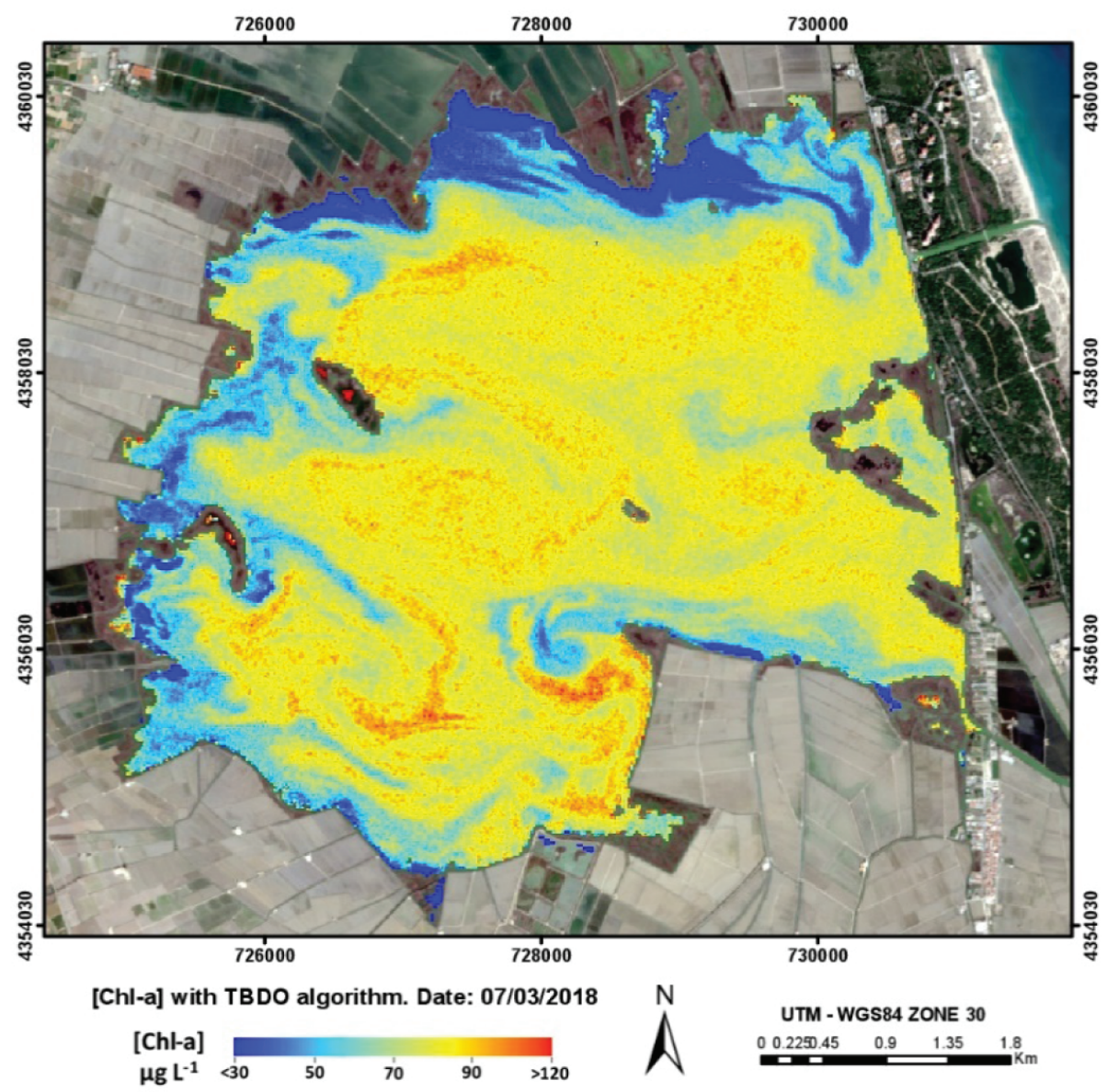

Figure 5. [Chl-a] map by TBDO algorithm in the Albufera of Valencia from S2-MSI image of 07/03/2018. Mapa de [Chl-a] aplicando el algoritmo TBDO en la Albufera de Valencia obtenido de la imagen S2-MSI del 07/03/2018.

\section{Calibration and validation of $\mathrm{Z}_{\mathrm{SD}}$ algorithms}

The calibration-validation process of algorithms for the $Z_{\mathrm{SD}}$ estimation, has been based on the relationship between the 490/560, 490/705 and
560/705 ratios and in situ $\mathrm{Z}_{\mathrm{SD}}$ measurements. Inspired by the algorithms described earlier, we have tested several regression models. The dataset collected in field campaigns over the study area consist of 79 measurements. It has a wide $\mathrm{Z}_{\mathrm{SD}}$ 
range from 0.25 to $10 \mathrm{~m}$. For the calibration and validation process, the dataset was divided into 2 groups: $75 \%$ of the data $(\mathrm{N}=60)$ was used to calibrate and $25 \%(\mathrm{~N}=19)$ to validate the ratios. In a first attempt, we tested the three algorithms applying the trophic classification followed in the [Chl-a] algorithm calibration, differentiating ultraoligotrophic-mesotrophic waters and eutrophic-hypertophic waters, but the results were not optimum due to the limited dataset used.

Figure 6 shows the results of the calibration process. Here, the logarithm of measured $Z_{S D}$ is represented, depending on the logarithm of each of the three indices. In Fig. 6 it is observed that the best fit is the linear one, and that for the calibration process, the 490/705 and 560/705 ratios showed the best performance in both cases.

To validate the $Z_{S D}$ algorithms, we applied the coefficients obtained in the calibration process to the different band ratios, as explained earlier. The validation data set consists of 19 measurements ( $25 \%$ of total). Figure 7 show the results. To select the best method, Table 5 shows the three formulas obtained in the calibration process and the statistics of the validation process. Considering all the statistics, the algorithm with the lowest error and the best correlation is $490 / 705$.

According to these results, the $490 / 705$ ratio is the most appropriate for estimating $\mathrm{Z}_{\mathrm{SD}}$ with an error MAE of $0.88 \mathrm{~m}$. We have applied this algorithm on the same S2-MSI scene that was used in the application of the [Chl- $a$ ] algorithm. We obtained a map that shows the different values of the water transparency of this hypertrophic lake (Fig. 8). For the Albufera of Valencia (Fig. 5 and Fig. 8), it can be observed that according to the 490/705 ratio, a vast majority of the lagoon had values between 0.30 to 0.36 meters. Once again, the correct match-up with the in situ $\mathrm{Z}_{\mathrm{SD}}$ was confirmed. According to the data measured this day, the $\mathrm{Z}_{\mathrm{SD}}$ was between 0.30 and $0.33 \mathrm{~m}$ (Table 3 ).

As can be seen in the [Chl-a] and the $\mathrm{Z}_{\mathrm{SD}}$ maps, the expected relationship between the minimum value of chlorophyll concentration and maximum water transparency is given in areas near shoreline. In the northern region, the concentration of chlorophyll is minimum, taking into account the values normally measured in Albufera of Valencia (See Table 3). Here the values are between 50 to $70 \mathrm{mg} / \mathrm{m}^{3}$, coinciding with maximum transparency, $\mathrm{Z}_{\mathrm{SD}}$ up to 0.38 meters, again matching-up with the values registered in this lagoon (Table 3). This high transparency is probably due to the early opening of water gates for rice crops that usually starts in May.

\section{DISCUSSION}

To estimate $[\mathrm{Ch}-a]$ and according to the error analysis $\left(\mathrm{MAE}=0.89 \mathrm{mg} / \mathrm{m}^{3}\right)$, the OC2_490

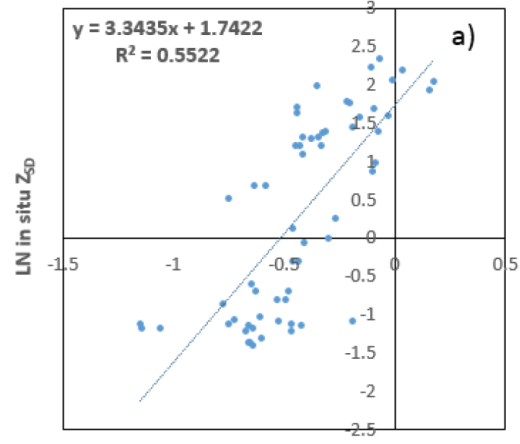

LN $490 / 560$

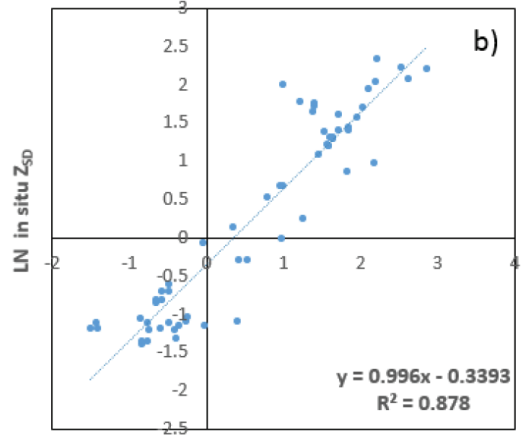

LN $490 / 705$

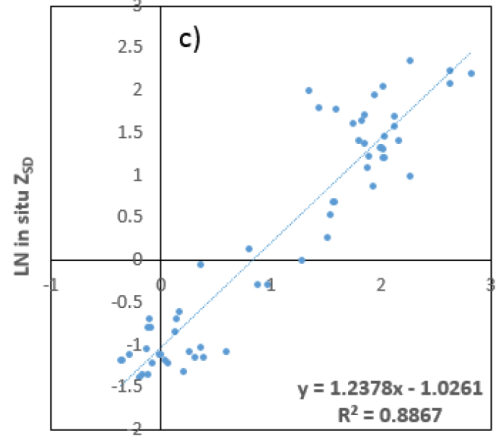

LN 560/705

Figure 6. Calibration of the $\mathrm{Z}_{\mathrm{SD}}$ algorithms. a) $490 / 560$ algorithm and in situ $\ln \left(\mathrm{Z}_{\mathrm{SD}}\right)$ linear fit. b) $490 / 705$ algorithm and in situ $\ln \left(Z_{\mathrm{SD}}\right)$ linear fit. and c) 560/705 algorithm and in situ $\ln \left(\mathrm{Z}_{\mathrm{SD}}\right)$ linear fit. Calibración de los algorimos para $Z_{S D}$. a) Ajuste lineal entre el algoritmo $490 / 560 y \ln \left(Z_{S D}\right)$ in situ. b) Ajuste lineal entre el algoritmo 490/705 y $\ln \left(Z_{S D}\right)$ in situ, y c) Ajuste lineal entre el algoritmo $560 / 705$ y $\ln \left(Z_{S D}\right)$ in situ. 

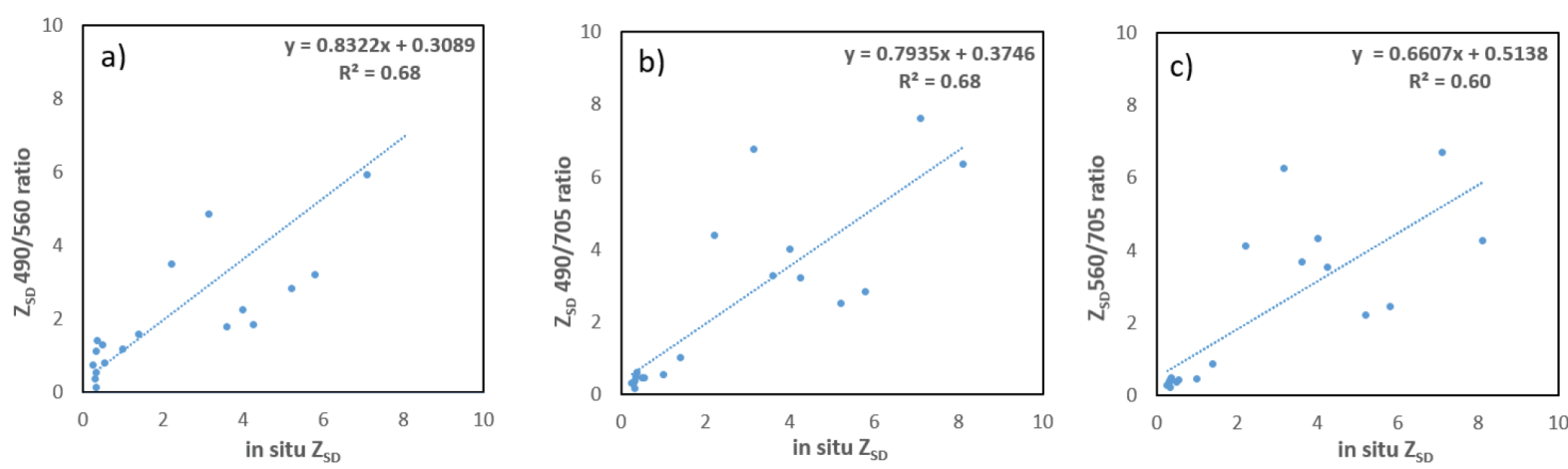

Figure 7. Validation of the $Z_{S D}$ algorithms. a) $Z_{S D}$ calculated with the $490 / 560$ ratio in relation with in situ $Z_{S D}$. b) $Z_{S D}$ calculated with the 490/705 ratio in relation with in situ $Z_{S D}$ validation. c) $Z_{S D}$ calculated with the 560/705 ratio in relation with in situ $Z_{S D}$. Validación de los algorimos para $Z_{S D}$. a) $Z_{S D}$ calculada con el ratio 490/560 en relación a $Z_{S D}$ medida in situ. b) $Z_{S D}$ calculada con el ratio 490/705 en relación a $Z_{S D}$ medida in situ. c) $Z_{S D}$ calculada con el ratio 560/705 en relación a $Z_{S D}$ in situ.

Table 5. Equations for the $\mathrm{Z}_{\mathrm{SD}}$ estimation and statistics of the validation process. Ecuaciones para la estimación de $Z_{S D} y$ estadísticos del proceso de validación.

\begin{tabular}{ccccc}
\hline Algorithm & Equation $\left(Z_{\mathrm{SD}}\right.$ in $\left.\mathrm{m}\right)$ & $\mathbf{R}^{2}$ & MAE & Bias \\
\hline $490 / 560$ & $\mathrm{Z}_{\mathrm{SD}}=\mathrm{e}^{\wedge}\left(3.3435^{*} \ln (\mathrm{Rrs}\right.$ 490/Rrs_560) +1.7422$)$ & 0.68 & 1.16 & 0.12 \\
$490 / 705$ & $\mathrm{Z}_{\mathrm{SD}}=\mathrm{e}^{\wedge}(0.996 * \ln (\mathrm{Rrs} 4490 / \mathrm{Rrs}$ 705 $)-0.3393)$ & 0.68 & 0.88 & 0.15 \\
$560 / 705$ & $\mathrm{Z}_{\mathrm{SD}}=\mathrm{e}^{\wedge}(1.2378 * \ln (\mathrm{Rrs}$ 560/Rrs_705)-1.0261) & 0.60 & 0.96 & 0.35 \\
\hline
\end{tabular}

algorithm should be preferred for low values $\left([\mathrm{Chl}-a]=<10 \mathrm{mg} / \mathrm{m}^{3}\right)$, as is the case of the reservoirs of Benagéber, Contreras, Sitjar, Tous, Beniarrés, María Cristina and Regajo. While Ocean Color algorithms have a longer tradition in ocean studies, the optimum results achieved in this study suggest they could have broad applicability on some types of inland waters. The validation of the TBDO algorithm gave a good result in eutrophic to hypertrophic water mass with $[$ Chl- $a]>10 \mathrm{mg} / \mathrm{m}^{3}$, such as the Albufera of Valencia and the Bellús reservoir. The results obtained in this study ratify the ones obtained by Guibaja et al. (2016) on the applicability of this algorithm on eutrophic to hypertrophic water masses. The match-up obtained between the TBDO application over the S2-MSI image and the values measured in situ the same day confirms the validity of the TBDO algorithm in water masses with high value of chlorophyll- $a$.
To estimate the $\mathrm{Z}_{\mathrm{SD}}$, we have obtained an optimum result with the 490/705 band ratio. While it is true that the environment and natural conditions between the Baltic Sea and the reservoirs of the Valencia region are different, the $Z_{\text {SD }}$ range $(0.25$ to $10.5 \mathrm{~m})$ measured in our study area is similar to that measured by Alikas \& Kratzer (2017) in Himmerfjärden Lake (1.9 to $7.5 \mathrm{~m})$. As happened with the $[\mathrm{Chl}-a]$, the match-up obtained between the 490/705 ratio application over the S2-MSI image and the values measured in situ the same day confirms the validity of this algorithm in water masses with lower water transparency value.

Regarding the applicability of the three algorithms by trophic states as we did for the [Chl- $a$ ] algorithms, we concluded that is not appropriate due to a) the limited dataset for the calibration-validation process and $b$ ) the composition of suspended solids of water, due to similar $Z_{\mathrm{SD}}$ 


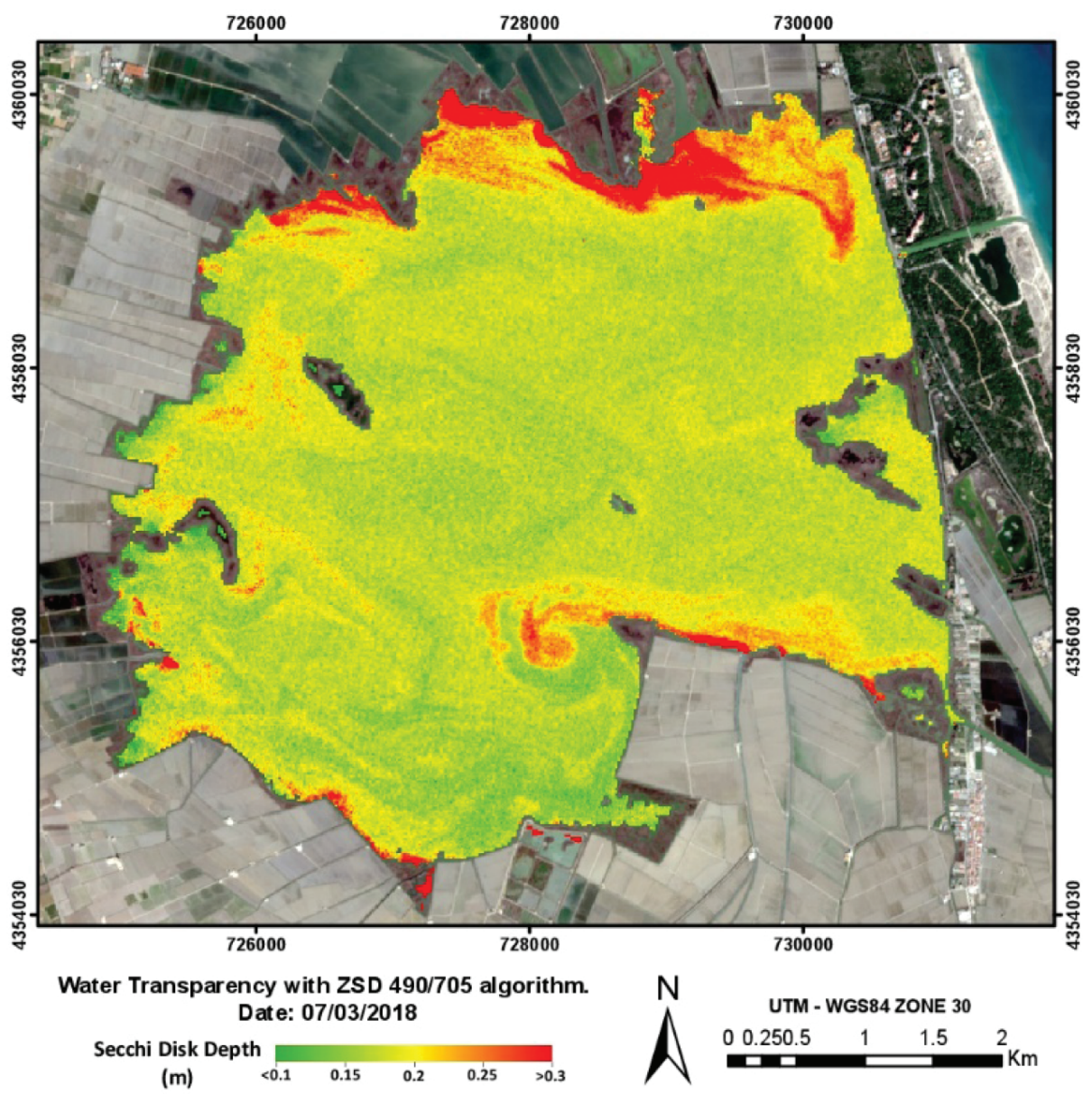

Figure 8. Z $\mathrm{SD}$ map by 490/705 ratio in the Albufera of Valencia. S2-MSI image of 07/03/2018. Mapa de $Z_{S D}$ aplicando el ratio 490/705 en la Albufera de Valencia. Imagen S2-MSI del 07/03/2018.

values have different [Chl-a]; this is produced by the presence of NAP giving turbidity to water but without pigments. In this way, Yang et al. (2013) also proposed two quasi-analytical algorithms to retrieve total absorption and backscattering coefficients based on a semi-analytical estimation model for clear and turbid inland waters, and these models could be proved in future works. There are many works were $\mathrm{Z}_{\mathrm{SD}}$ is not well estimated, as Devi Prasad \& Siddaraju (2012) in some Indian hypertrophic lakes; Borkman \& Smayda (1998) in coastal areas of Rhode Island and Lahtrop (1992) were algorithms derived from samples in Lake Michigan cannot be extrapolated to Yellowstone and Jackson Lakes.

\section{CONCLUSIONS}

The accuracy of the algorithms estimated in the reservoirs studied so far is sufficient for most of the applications related to the ecological status assessment. The S2-MSI images showed that they are optimum for performing ecological monitoring on inland waters from space.

It is important to emphasize the relevance of the atmospheric correction method used: Sen2Cor, which in our case was accurate enough, allows the algorithms to be applied to actual S2-MSI data for routine monitoring purposes, which is the ultimate goal of the ESAQS project. In this context, the next step of the research is to 
evaluate and validate several atmospheric correction methods for different types of inland water in order to determine the one best suited for achieving the ESAQS objectives.

\section{ACKNOWLEDGEMENTS}

We would like to thank to the Generalitat Valenciana for the concession of the Prometeo program 2016/032 for the start-up and development of the ESAQS (Ecological Status of Aquatic Systems with Sentinel satellites) project. We also thank the Confederación Hidrográfica del Júcar for their support in the field campaigns carried out in this project, and to the Spanish National Institute for Aerospace Technology (INTA) for allowing us to generate the HydroLight database.

\section{REFERENCES}

ALIKAS, K. \& S. KRATZER. 2017. Improved retrieval of Secchi depth for optically-complex waters using remote sensing data. Ecological indicators, 77: 218-227.

ANTOINE, D. 2010. Sentinel-3 Optical products and algorithm definition. OLCI Level 2 Algorithm Theoretical Basis Document Transparency Products in case 1 waters, 13.

AUSTIN, R. W. \& T. J. PETZOLD. 1981. The determination of the diffuse attenuation coefficient of sea water using the Coastal Zone Color Scanner. Oceanography from Space, 239-256.

BORKMAN, D. G. \& T. J. SMAYDA. 1998. Long-term trends in water clarity revealed by Secchi-disk measurements in lower Narragansett Bay, ICES Journal of Marine Science, 55(4), 668-679. DOI: 10.1006/jmsc. 1998.0380

BRICAUD, A., A. MOREL, M. BABIN, H. CLAUSTRE. 1995. Variability in the chlorophyll-specific absorption coefficients of natural phytoplankton: Analysis and parametrization. Journal of Geophysical Research. DOI: 10.1029/95JC00463

CASPERS, H. 1984. OECD: Eutrophication of Waters. Monitoring, Assessment and Control. -154 pp. Paris: Organisation for Economic Co-Operation and Development 1982 (Publié en français sous le titre» Eutrophication des
Eaux. Méthodes de Surveillance, d'Evaluation et de Lutte «). International Review of Hydrobiology, 69(2): 200-200.

DALL'OLMO, G., A. A. GITELSON \& D. C. RUNDQUIST. 2003. Towards a unified approach for remote estimation of chlorophyll-a in both terrestrial vegetation and turbid productive waters. Geophysical Research Letters, 30:18

D'ODORICO, P., A. GONSAMO, A. DAMM \& E. SCHAEPMAN. 2013. Experimental evaluation of Sentinel-2 Spectral Response Function for NDVI time-series continuity. IEE Transactions on Geoscience and Remote Sensing, 51(3): 1336-1348.

DEVI PRASAD, A.G. \& SIDDARAJU, K., 2012. Application of CCME WQI to lakes of Mandya, Karnataka State, India. On. Internat. Interdispl. Res. J., 2(1): 108-114.

DORON, M., M. BABIN, A. MANGIN \& O. HEMBISE. 2007. Estimation of light penetration, and horizontal and vertical visibility in oceanic and coastal waters from surface reflectance. Journal of Geophysical Research: Oceans, 112(C6). DOI: 10.1029/ 2006JC004007

ESA 2018a. Spectral Response Function. (Available on: https://earth.esa.int/web/sentinel/userguides/sentinel-2-msi/document-library/-/ asset_publisher/Wk0TKajiISaR/content/ sentinel-2a-spectral-responses). Last time consulted: 01/02/2018.

ESA 2018b. Sentinel images. (Available on: https://scihub.copernicus.eu/dhus/). Last time consulted: 01/02/2018.

ESA 2018c. SNAP software. Version 5.0. (Available on: http://step.esa.int/main/download/). Last time consulted: 01/02/2018.

ESA 2018d. Sen2Cor plugin. Version 2.4.0. (Available on: http://step.esa.int/main/thirdparty-plugins- $2 / \operatorname{sen} 2$ cor/). Last time consulted: $01 / 02 / 2018$.

FARGION, G. S., and J. L. MUELLER (eds.) 2000. Ocean Optics Protocols for Satellite Ocean Color Sensor Validation, Vol. Revision 2. National Aeronautical and Space Administration. Goddard Space Flight Center. Greenbelt, Maryland, $184 \mathrm{p}$.

GIARDINO, C., M. PEPE, P. A. BRIVIO, P. 
GHEZZI \& E. ZILIOLI. 2001. Detecting chlorophyll, Secchi disk depth and surface temperature in a sub-alpine lake using Landsat imagery. Science of the Total Environment, 268(1-3): 19-29.

GILERSON, A. A., A. A. GITELSON, J. ZHOU, D. GURLIN, M. WESLEY, I. IANNOU \& S. AHMED. 2010. Algorithms for remote estimation of chlorophyll-a in coastal and inland waters using red and near infrared bands. Optic Express, 18(23): 24109-24125.

GUIBAJA, G., A. RUIZ-VERDÚ, S. ROMO, J. M. SORIA, C. TENJO, M. PEREIRA-SANDOVAL, J. DELEGIDO, R. PEÑA \& J. MORENO. 2016. Mapping water quality in the Albufera of Valencia lake with the new Sentinel-2 Earth Observation satellite. XVIII Iberian Congress of Limnology. IRTA. July 4-8, 2016. Tortosa, Spain.

JEFFREY, S. T. \& G. F. HUMPHREY. 1975. New spectrophotometric equations for determining chlorophylls a, b, c1 and c2 in higher plants, algae and natural phytoplankton. Biochemie und Physiologie der Pflanzen. 167: 191-194.

KOPONEN, S., J. PULLIAINEN, K. KALLIO \& M. HALLIKAINEN. 2001. Lake water quality classification with airborne hyperspectral spectrometer and simulated MERIS data. Remote Sensing of Environment, 79(1): 51-59. KRATZER, S., C. BROCKMANN \& G. MOORE. 2008. Using MERIS full resolution data to monitor coastal waters - A case study from Himmerfjärden, a fjord-like bay in the northwestern Baltic Sea. Remote Sensing of Environment, 112(5): 2284-2300.

LATHROP, R. G. 1992. Landsat Thematic Mapper monitoring of turbid inland water quality. Photogrammetric Engineering and Remote Sensing, 58: 465-470.

MOBLEY, C. 1994. Light and Water: Radiative Transfer in Natural Waters. Academic Press.

MOBLEY, C. 1999. Estimation of the remote-sensing reflectance from above-surface measurements. Applied optics, 38(36): 7442-7455.

MUELLER, J. L. 2000. SeaWIFS algorithm for the diffuse attenuation coefficient, K (490), using water-leaving radiances at 490 and 555 nm. SeaWiFS postlaunch calibration and validation analyses, 3: 24-27.

O'REILLY, J. E. et al. 2000. Ocean color chlorophyll-a algorithms for SeaWiFS, OC2, and OC4: Version 4. SeaWi-FS postlaunch calibration and validation analyses, Part, 3: 9-23.

PREISENDORFER, R. 1986. Secchi disk science: Visual optics of natural waters1. Limnology and Oceanography. Volume 31, Issue 5. DOI: 10.4319/1o.1986.31.5.0909

RUIZ-VERDÚ, A., J. C. JIMÉNEZ, X. LAZZARO, C. TENJO, J. DELEGIDO, M. PEREIRA, J. SOBRINO \& J. MORENO. 2016. Comparison of MODIS and LANDSAT-8 retrievals of chlorophyll- $a$ and water temperature over Lake Titicaca. XVIII Iberian Congress of Limnology. IRTA. July 4-8, 2016. Tortosa, Italy.

RUESCAS, A. B., M. PEREIRA-SANDOVAL, C. TENJO, A. RUIZ- VERDÚ, F. STEINMETZ \& L. DE KEUKELAERE. 2016. Sentinel-2 atmospheric correction inter-comparison over two lakes in Spain and Peru-Bolivia. CLEO (Colour and Light in the Ocean from Earth Observation). ESA-ESRIN. September 6-8, 2016. Frascati, Rome, Italy.

SORIA, X., J. DELEGIDO, E. P. URREGO, M. PEREIRA-SANDOVAL, E. VICENTE, A. RUIZ-VERDÚ, J. M. SORIA, R. PEÑA, C. TENJO \& J. MORENO. 2017a. Validación de algoritmos para la estimación de la Clorofila-a con Sentinel-2 en la Albufera de Valencia. Teledetección: Nuevas plataformas y sensores aplicados a la gestión del agua, la agricultura y el medio ambiente. XVII Congreso de la Asociación Española de Teledetección. October 3-7, 2017. Murcia, Spain. 293-296.

SORIA, X., E. VICENTE, C. DURÁN, J. M. SORIA, R. PEÑA. 2017b. Uso de imágenes Landsat-8 para la estimación de la profundidad del disco de Secchi en aguas continentales. Teledetección: Nuevas plataformas y sensores aplicados a la gestión del agua, la agricultura y el medio ambiente. XVII Congreso de la Asociación Española de Teledetección. October 3-7, 2017. Murcia, Spain. 293-296.

SORIA, X., E. P. URREGO, M. PEREIRA-SANDOVAL, A. RUIZ-VERDÚ, R. PEÑA, J. M. SORIA, J. DELEGIDO, E. VICENTE \& J. 
MORENO. 2019. Monitoring the ecological state of a hypertrophic lake (Albufera of València, Spain) using multitemporal Sentinel-2 images. Limnetica, 38(1): 457-469. DOI: 10.23818/limn.38.26

SHOAF, W. T. \& B. W. LIUM. 1976. Improved extraction of chlorophyll $a$ and $b$ from algae using dimethyl sulphoxide. Limnology and. Oceanography, 21: 926-928.

STRAMSKI, D., A. BRICAUD, A. MOREL. 2001. Modeling the Inherent Optical Properties of the Ocean Based on the Detailed Composition of the Planktonic Community. Applied Optics. 40 (18): 2929-2945. DOI: 10.1364/AO.40.002929
YANG, W., B. MATSUSHITA, J. CHEN, K. YOSHIMURA \& T. FUKUSHIMA. 2013. Retrieval of inherent optical properties for turbid inland waters from remote-sensing reflectance. IEEE Transactions on Geoscience and Remote Sensing, 51: 3761-3773. DOI: 10.1109/TGRS.2012.2220147

ZHENG, G. and P.M. DIGIACOMO. 2017. Detecting phytoplankton diatom fraction based on the spectral shape of satellite-derived algal light absorption coefficient. Limnology and Oceanography. Association for the Sciences of Limnology and Oceanography. DOI: 10.1002/lno.10725

Con el apoyo de:
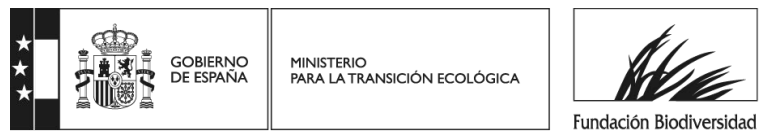